\title{
Combination of endostatin and vinorelbine enhances control of breast cancer cells while endostatin ameliorates the toxicity of vinorelbine in normal cells
}

\author{
A. Cansu Kilit, E.A. Aydemir and K. Fiskin \\ Department of Biology, Faculty of Science, Akdeniz University, 07058, \\ Antalya, Turkey \\ Corresponding author: A. Cansu Kilit \\ E-mail: acansukilit@gmail.com
}

Genet. Mol. Res. 19 (1): gmr18497

Received September 30, 2019

Accepted March 11, 2020

Published March 30, 2020

DOI http://dx.doi.org/10.4238/gmr18497

\begin{abstract}
Surgery, chemotherapy and radiotherapy, which are known as conventional cancer treatments, have been applied for more than 40 years. Because the target of chemotherapy is tumor cells, treatment agents are used at high doses during application and this creates toxic responses, causing side effects in normal cells. Furthermore, due to the high doses, cancer cells develop resistance to the agent and, as a result, success of the treatment gradually decreases. That is why chemotherapy is combined with various other cancer treatments to increase the therapeutic efficacy while reducing the side effects. In this study, the cytotoxic effect of endostatin, vinorelbine and their combination on breast cancer cell line MDAMB 231 was researched in vitro. In addition, the effects caused by the combination on TRAIL, TNF- $\alpha$ and caspase-2, 3, 6, 8 and -9 proteins, which undertake key roles in apoptosis were investigated. Cytotoxic effects of both agents and their combinations on normal epithelial cells $(293 \mathrm{~T})$ were also studied and compared. We found that endostatin is cytotoxic for cancer cells through caspase- 8 and TNF- $\alpha$ activation, which affects the extrinsic pathway of apoptosis Combining endostatin as an anti-angiogenic agent with vinorelbine
\end{abstract}


significantly suppressed the cytotoxicity that vinorelbine exerts on normal cells.

Key words: Endostatin; Vinorelbine; MDAMB 231; TNF- $\alpha$; TRAIL

\section{INTRODUCTION}

Cancer is a complex, multifactorial heterogeneous disease that involves uncontrolled multiplication and metastasis of abnormal form of normal cells (Jemal et al., 2011; Ravishankar et al., 2013). To date cancer is still one of the most important causes of mortality worldwide, although rapid advances have been made to improve both diagnostic and therapeutic methods (Ai et al., 2013). The World Health Organization (WHO) projects that the global number of deaths because of cancer will increase nearly $80 \%$ by 2030 (Jemal et al., 2011; Ai et al., 2013; Ravishankar et al., 2013).

Breast cancer is a common malignant tumor and is the cause of the majority of cancer mortality in females. Although chemotherapeutic agents have been extensively used for the treatment of breast cancer, the side effects and drug resistance associated with chemotherapy have limited its effectiveness (Amirzada et al., 2014; Lin et al., 2014; Zu et al., 2015).

To increase the efficacy of existing chemotherapeutic drugs, many different drug combinations are tested as an alternative method of breast cancer treatment. It may be possible to eliminate cancer cells by targeting unique features that are necessary for turning a normal cell into a cancer cell. Since cancer cells are known to develop resistance to apoptosis, trigger this mechanism in cancer cells is desirable (Hayakawa et al, 2008). Stimulation of apoptosis in tumor cells can be achieved either by triggering the expression of pro-apoptotic factors or suppressing the expression of anti-apoptotic factors (Ozben, 2007). Basically, in mammals apoptosis can be stimulated in three different ways: (1) extrinsic pathway induced by activation of caspase- 8 upon binding of death receptors; (2) the intrinsic pathway initiated by cellular stress and subsequent caspase-9 activation and (3) the granzyme B pathway, in which the protease granzyme B is transferred to sensitive target cells (Ghavamii et al., 2009). All these pathways converge to a common execution phase of apoptosis in which caspases-3 and/or -7 are proteolytically activated from their inactive zymogens (Salvesen and Dixit, 1997). Fas (fibroblast associated antigen, also called Apo-1 or CD95) and tumor necrosis factor receptors (TNF-R) belong to TNF-R family and they contain a cytosolic death domain (DD). Death receptor ligation causes the formation of death inducing signaling complex (DISC) where the adaptor proteins TRADD and/or FADD bind with their death domain (DD) to the same domain in the cytoplasmic region of the receptors leading to the recruitment of initiator caspases; caspase-8 or -10, to the DISC. The activated caspase then proteolytically activates downstream executioner caspases which are able to degrade different cellular targets (Ghavami et al., 2009). TRAIL is a member of the TNF superfamily and is constitutively expressed in many tissues (Wiley et al., 1995). TRAIL interacts with five different receptors. Basically, the signaling cascade initiated by TRAIL after binding to its death receptors is known as the extrinsic pathway of apoptosis (Amarante-Mendes and Griffith, 2015).

Angiogenesis described as the formation of new blood vessels from existing ones, is one of the important features that is needed for transformation of normal cells into cancer 
cells since nutrient and oxygen needed by tumor cells are derived from blood vessels. Inhibition of angiogenesis is an important target for cancer treatment (Connolly et al., 2002). Some of the angiogenesis inhibitors are currently used to treat cancer. Endostatin, which is at the C-terminus of collagen XVIII with a molecular weight of $20 \mathrm{kDa}$, is an endogenous anti-angiogenic protein (O'Reilly et al., 1997). It's known that endostatin can induce apoptosis by inhibiting endothelial cell migration and thereby inhibits tumors from creating new blood vessels (O'Reilly et al., 1997; Wen et al., 1999; Kalluri et al., 2003).

Vinorelbine is a vinca alkaloid with a semi-synthetic character that is effective through "inhibition of mitotic microtubule polymerization". vinorelbine has provided better results as well as rising less toxic side effects in breast cancer and non-small cell lung cancer treatment. Additionally, it may be used alone and increases the success rates of combined treatments as well (Hayakawa et al., 2008). The combination of vinorelbine, which is a chemotherapeutic drug, and endostatin as an anti-angiogenic agent, may enable a double-sided battle with breast cancer cells. Based on this hypothesis, we investigated the cytotoxic and apoptotic effects of endostatin and vinorelbine, alone and in combination, on MDAMB 231 human breast cancer cells.

\section{MATERIAL AND METHODS}

\section{Drugs}

Recombinant human endostatin, expressed in Pichia pastoris, in citrate phosphate buffer (17 mM citric acid, $66 \mathrm{mM}$ sodium phosphate dibasic, $59 \mathrm{mM}$ sodium chloride, at $\mathrm{pH}$ 6.2) was purchased from Calbiochem (San Diego, CA, USA). The endostatin was thawed, gently mixed and aliquoted into standard micro Eppendorf tubes in quantities of $10 \mu \mathrm{L}$ for daily assays. Vinorelbine (ditartate salt hydrate $>98 \%$ (HPLC)) was purchased in powder form from Sigma (Sigma Chemical Co., St. Louis, MO, USA). The aliquots were stored at $-80^{\circ} \mathrm{C}$ until needed.

\section{Cell lines and in vitro culture conditions}

The human breast cancer cell line (MDAMB 231) and kidney epithelial cell line $(293 \mathrm{~T})$ were obtained from ATCC. The cells were maintained in RPMI 1640 medium supplemented with $10 \%$ fetal bovine serum (FBS), $2 \mathrm{mM}$ L-glutamine, $1 \mathrm{mM}$ sodium pyruvate and $0.02 \mathrm{mM}$ non-essential amino acids. The cell lines were maintained at $37^{\circ} \mathrm{C}$ in a humidified atmosphere of $5 \% \mathrm{CO}_{2}$.

\section{Cell viability}

To assess the cytotoxic effects of endostatin, vinorelbine and the combination (endostatin + vinorelbine) on MDAMB 231 and 293 T cells in vitro, initial studies were performed to determine the optimal drug concentrations. Cells were plated at a density of $1 \times 10^{4}$ cell/well on sterile 96 -well plates. After $36 \mathrm{~h}$ of plating, the cells were treated with endostatin and vinorelbine in medium supplemented with $1 \% \mathrm{FBS}$, with eight repeats of each treatment. The application method of the combination of endostatin and vinorelbine is shown in Table 1. A "checkerboard" like microplate method was applied to study the 
effects of endostatin and vinorelbine interactions on cells (Kars et al., 2008). Endostatin and vinorelbine were applied to the wells simultaneously. Immediately after the application of drugs, cell viability in a single column was determined and recorded as time zero. The plain medium with $1 \%$ FBS was used as negative control. The viability of MDAMB 231 and 293 T cells after 24, 48 and 72h was determined using WST-1 cell proliferation kit (Roche, Cat. No. 11644807001) according to the manufacturer's instructions. Formation of formasan was determined at an optical density (OD) $450 \mathrm{~nm}$ wavelength and was compared between the groups. To calculate the percentage of growth inhibition the following formula was used: growth inhibition $(\%)=[($ mean OD value of control group- mean OD value of treatment group)/mean OD value of control group] $x 100 \%$.

Table 1. Experimental design of endostatin (ES), vinoralbine (VL) and combination treatment using 'checkerboard' type application. The dilutions of VL were made horizontally, whereas the dilutions of ES were made vertically in a 96 well plate in $200 \mu \mathrm{L}$.

\begin{tabular}{|c|c|c|c|c|c|c|c|c|c|c|c|}
\hline \multirow[b]{2}{*}{ Control } & \multirow[b]{2}{*}{ Control } & \multirow[b]{2}{*}{$1 \mu \mathrm{g} / \mathrm{mL}$} & \multirow{2}{*}{$\begin{array}{c}\text { ES } \\
500 \\
\mathrm{ng} / \mathrm{mL} \\
500\end{array}$} & \multirow{2}{*}{$\begin{array}{c}\mathbf{E S} \\
250 \\
\mathrm{ng} / \mathrm{mL}\end{array}$} & \multirow{2}{*}{$\begin{array}{c}\text { ES } \\
125 \\
\mathrm{ng} / \mathrm{mL}\end{array}$} & \multirow{2}{*}{$\begin{array}{c}\text { ES } \\
62.5 \\
\mathrm{ng} / \mathrm{mL}\end{array}$} & \multirow{2}{*}{$\begin{array}{c}\text { ES } \\
31.25 \\
\mathrm{ng} / \mathrm{mL}\end{array}$} & \multirow{2}{*}{$\begin{array}{c}\text { ES } \\
15.62 \\
\mathrm{ng} / \mathrm{mL}\end{array}$} & \multirow{2}{*}{$\begin{array}{c}\text { ES } \\
7.81 \\
\mathrm{ng} / \mathrm{mL}\end{array}$} & \multirow{2}{*}{$\begin{array}{c}\text { ES } \\
3.90 \\
\mathrm{ng} / \mathrm{mL}\end{array}$} & \multirow{2}{*}{$\begin{array}{c}\mathbf{E S} \\
1.95 \\
\mathrm{ng} / \mathrm{mL} \\
1.95 \\
\mathrm{ng} / \mathrm{mL}\end{array}$} \\
\hline & & & & & & & & & & & \\
\hline Control & $\begin{array}{c}\mathrm{VL} \\
1 \mu \mathrm{g} / \mathrm{mL}\end{array}$ & $\begin{array}{c}1 \mu \mathrm{g} / \mathrm{mL} \\
+ \\
1 \mu \mathrm{g} / \mathrm{mL}\end{array}$ & $\begin{array}{c}\mathrm{ng} / \mathrm{mL} \\
+ \\
1 \mu \mathrm{g} / \mathrm{mL}\end{array}$ & $\begin{array}{c}250 \\
\mathrm{ng} / \mathrm{mL}+ \\
1 \mu \mathrm{g} / \mathrm{mL}\end{array}$ & $\begin{array}{c}125 \\
\mathrm{ng} / \mathrm{mL}+ \\
1 \mu \mathrm{g} / \mathrm{mL}\end{array}$ & $\begin{array}{c}62.5 \\
\mathrm{ng} / \mathrm{mL}+ \\
1 \mu \mathrm{g} / \mathrm{mL}\end{array}$ & $\begin{array}{c}31.25 \\
\mathrm{ng} / \mathrm{mL}+ \\
1 \mu \mathrm{g} / \mathrm{mL}\end{array}$ & $\begin{array}{c}15.62 \\
\mathrm{ng} / \mathrm{mL}+ \\
1 \mu \mathrm{g} / \mathrm{mL}\end{array}$ & $\begin{array}{c}7.81 \\
\mathrm{ng} / \mathrm{mL}+ \\
1 \mu \mathrm{g} / \mathrm{mL}\end{array}$ & $\begin{array}{c}3.90 \\
\mathrm{ng} / \mathrm{mL}+ \\
1 \mu \mathrm{g} / \mathrm{mL}\end{array}$ & $\begin{array}{c}\mathrm{ng} / \mathrm{mL} \\
+ \\
1 \mu \mathrm{g} / \mathrm{ml} \\
1.95\end{array}$ \\
\hline \multirow[t]{2}{*}{$\begin{array}{l}\text { Control } \\
\text { Control }\end{array}$} & $\begin{array}{c}\mathrm{VL} \\
500 \\
\mathrm{ng} / \mathrm{mL} \\
\mathrm{VL}\end{array}$ & $\begin{array}{c}1 \mu \mathrm{g} / \mathrm{mL} \\
+ \\
500 \\
\mathrm{ng} / \mathrm{mL}\end{array}$ & $\begin{array}{c}500 \\
\mathrm{ng} / \mathrm{mL}+ \\
500 \\
\mathrm{ng} / \mathrm{mL}\end{array}$ & $\begin{array}{c}250 \\
\mathrm{ng} / \mathrm{mL}+ \\
500 \\
\mathrm{ng} / \mathrm{mL}\end{array}$ & $\begin{array}{c}125 \\
\mathrm{ng} / \mathrm{mL}+ \\
500 \\
\mathrm{ng} / \mathrm{mL}\end{array}$ & $\begin{array}{c}62.5 \\
\mathrm{ng} / \mathrm{mL}+ \\
500 \\
\mathrm{ng} / \mathrm{mL}\end{array}$ & $\begin{array}{c}31.25 \\
\mathrm{ng} / \mathrm{mL}+ \\
500 \\
\mathrm{ng} / \mathrm{mL}\end{array}$ & $\begin{array}{c}15.62 \\
\mathrm{ng} / \mathrm{mL}+ \\
500 \\
\mathrm{ng} / \mathrm{mL}\end{array}$ & $\begin{array}{c}7.81 \\
\mathrm{ng} / \mathrm{mL}+ \\
500 \\
\mathrm{ng} / \mathrm{mL}\end{array}$ & $\begin{array}{c}3.90 \\
\mathrm{ng} / \mathrm{mL}+ \\
500 \\
\mathrm{ng} / \mathrm{mL}\end{array}$ & $\begin{array}{c}\mathrm{ng} / \mathrm{mL} \\
+ \\
500 \\
\mathrm{ng} / \mathrm{mL}\end{array}$ \\
\hline & $\begin{array}{c}250 \\
\mathrm{ng} / \mathrm{mL}\end{array}$ & $\begin{array}{c}1 \mu \mathrm{g} / \mathrm{mL} \\
+ \\
250 \\
\mathrm{ng} / \mathrm{mL}\end{array}$ & $\begin{array}{c}500 \\
\mathrm{ng} / \mathrm{mL}+ \\
250 \\
\mathrm{ng} / \mathrm{mL}\end{array}$ & $\begin{array}{c}250 \\
\mathrm{ng} / \mathrm{mL}+ \\
250 \\
\mathrm{ng} / \mathrm{mL}\end{array}$ & $\begin{array}{c}125 \\
\mathrm{ng} / \mathrm{mL}+ \\
250 \\
\mathrm{ng} / \mathrm{mL}\end{array}$ & $\begin{array}{c}62.5 \\
\mathrm{ng} / \mathrm{mL}+ \\
250 \\
\mathrm{ng} / \mathrm{mL}\end{array}$ & $\begin{array}{c}31.25 \\
\mathrm{ng} / \mathrm{mL}+ \\
250 \\
\mathrm{ng} / \mathrm{mL}\end{array}$ & $\begin{array}{c}15.62 \\
\mathrm{ng} / \mathrm{mL}+ \\
250 \\
\mathrm{ng} / \mathrm{mL}\end{array}$ & $\begin{array}{c}7.81 \\
\mathrm{ng} / \mathrm{mL}+ \\
250 \\
\mathrm{ng} / \mathrm{mL}\end{array}$ & $\begin{array}{c}3.90 \\
\mathrm{ng} / \mathrm{mL}+ \\
250 \\
\mathrm{ng} / \mathrm{mL}\end{array}$ & $\begin{array}{c}1.95 \\
\mathrm{ng} / \mathrm{mL} \\
250 \\
\mathrm{ng} / \mathrm{mL}\end{array}$ \\
\hline Control & $\begin{array}{c}125 \\
\mathrm{ng} / \mathrm{mL}\end{array}$ & $\begin{array}{c}1 \mu \mathrm{g} / \mathrm{mL} \\
+ \\
125 \\
\mathrm{ng} / \mathrm{mL}\end{array}$ & $\begin{array}{c}500 \\
\mathrm{ng} / \mathrm{mL}+ \\
125 \\
\mathrm{ng} / \mathrm{mL}\end{array}$ & $\begin{array}{c}250 \\
\mathrm{ng} / \mathrm{mL}+ \\
125 \\
\mathrm{ng} / \mathrm{mL}\end{array}$ & $\begin{array}{c}125 \\
\mathrm{ng} / \mathrm{mL}+ \\
125 \\
\mathrm{ng} / \mathrm{mL}\end{array}$ & $\begin{array}{c}62.5 \\
\mathrm{ng} / \mathrm{mL}+ \\
125 \\
\mathrm{ng} / \mathrm{mL}\end{array}$ & $\begin{array}{c}31.25 \\
\mathrm{ng} / \mathrm{mL}+ \\
125 \\
\mathrm{ng} / \mathrm{mL}\end{array}$ & $\begin{array}{c}15.62 \\
\mathrm{ng} / \mathrm{mL}+ \\
125 \\
\mathrm{ng} / \mathrm{mL}\end{array}$ & $\begin{array}{c}7.81 \\
\mathrm{ng} / \mathrm{mL}+ \\
125 \\
\mathrm{ng} / \mathrm{mL}\end{array}$ & $\begin{array}{c}3.90 \\
\mathrm{ng} / \mathrm{mL}+ \\
125 \\
\mathrm{ng} / \mathrm{mL}\end{array}$ & $\begin{array}{c}1.95 \\
\mathrm{ng} / \mathrm{mL}+ \\
125 \\
\mathrm{ng} / \mathrm{mL}\end{array}$ \\
\hline Control & $\begin{array}{c}62.5 \\
\mathrm{ng} / \mathrm{mL}\end{array}$ & $\begin{array}{c}1 \mu \mathrm{g} / \mathrm{mL} \\
+ \\
62.5 \\
\mathrm{ng} / \mathrm{mL}\end{array}$ & $\begin{array}{c}500 \\
\mathrm{ng} / \mathrm{mL}+ \\
62.5 \\
\mathrm{ng} / \mathrm{mL}\end{array}$ & $\begin{array}{c}250 \\
\mathrm{ng} / \mathrm{mL}+ \\
62.5 \\
\mathrm{ng} / \mathrm{mL}\end{array}$ & $\begin{array}{c}125 \\
\mathrm{ng} / \mathrm{mL}+ \\
62.5 \\
\mathrm{ng} / \mathrm{mL}\end{array}$ & $\begin{array}{c}62.5 \\
\mathrm{ng} / \mathrm{mL}+ \\
62.5 \\
\mathrm{ng} / \mathrm{mL}\end{array}$ & $\begin{array}{c}31.25 \\
\mathrm{ng} / \mathrm{mL}+ \\
62.5 \\
\mathrm{ng} / \mathrm{mL}\end{array}$ & $\begin{array}{c}15.62 \\
\mathrm{ng} / \mathrm{mL}+ \\
62.5 \\
\mathrm{ng} / \mathrm{mL}\end{array}$ & $\begin{array}{c}7.81 \\
\mathrm{ng} / \mathrm{mL}+ \\
62.5 \\
\mathrm{ng} / \mathrm{mL}\end{array}$ & $\begin{array}{c}3.90 \\
\mathrm{ng} / \mathrm{mL}+ \\
62.5 \\
\mathrm{ng} / \mathrm{mL}\end{array}$ & $\begin{array}{c}1.95 \\
\mathrm{ng} / \mathrm{mL}+ \\
62.5 \\
\mathrm{ng} / \mathrm{mL}\end{array}$ \\
\hline \multirow[t]{2}{*}{ Control } & $\begin{array}{r}31.25 \\
\mathrm{ng} / \mathrm{mL}\end{array}$ & $\begin{array}{c}1 \mu \mathrm{g} / \mathrm{mL} \\
+ \\
31.25 \\
\mathrm{ng} / \mathrm{mL}\end{array}$ & $\begin{array}{c}500 \\
\mathrm{ng} / \mathrm{mL}+ \\
31.25 \\
\mathrm{ng} / \mathrm{mL}\end{array}$ & $\begin{array}{c}250 \\
\mathrm{ng} / \mathrm{mL}+ \\
31.25 \\
\mathrm{ng} / \mathrm{mL}\end{array}$ & $\begin{array}{c}125 \\
\mathrm{ng} / \mathrm{mL}+ \\
31.25 \\
\mathrm{ng} / \mathrm{mL}\end{array}$ & $\begin{array}{c}62.5 \\
\mathrm{ng} / \mathrm{mL}+ \\
31.25 \\
\mathrm{ng} / \mathrm{mL}\end{array}$ & $\begin{array}{c}31.25 \\
\mathrm{ng} / \mathrm{mL}+ \\
31.25 \\
\mathrm{ng} / \mathrm{mL}\end{array}$ & $\begin{array}{c}15.62 \\
\mathrm{ng} / \mathrm{mL}+ \\
31.25 \\
\mathrm{ng} / \mathrm{mL}\end{array}$ & $\begin{array}{c}7.81 \\
\mathrm{ng} / \mathrm{mL}+ \\
31.25 \\
\mathrm{ng} / \mathrm{mL}\end{array}$ & $\begin{array}{c}3.90 \\
\mathrm{ng} / \mathrm{mL}+ \\
31.25 \\
\mathrm{ng} / \mathrm{mL}\end{array}$ & $\begin{array}{c}1.95 \\
\mathrm{ng} / \mathrm{mL}+ \\
31.25 \\
\mathrm{ng} / \mathrm{mL}\end{array}$ \\
\hline & $\begin{array}{r}15.62 \\
\mathrm{ng} / \mathrm{mL}\end{array}$ & $\begin{array}{c}1 \mu \mathrm{g} / \mathrm{mL} \\
+ \\
15.62 \\
\mathrm{ng} / \mathrm{mL} \\
\end{array}$ & $\begin{array}{c}500 \\
\mathrm{ng} / \mathrm{mL}+ \\
15.62 \\
\mathrm{ng} / \mathrm{mL} \\
\end{array}$ & $\begin{array}{c}250 \\
\mathrm{ng} / \mathrm{mL}+ \\
15.62 \\
\mathrm{ng} / \mathrm{mL} \\
\end{array}$ & $\begin{array}{c}125 \\
\mathrm{ng} / \mathrm{mL}+ \\
15.62 \\
\mathrm{ng} / \mathrm{mL} \\
\end{array}$ & $\begin{array}{c}62.5 \\
\mathrm{ng} / \mathrm{mL}+ \\
15.62 \\
\mathrm{ng} / \mathrm{mL} \\
\end{array}$ & $\begin{array}{c}31.25 \\
\mathrm{ng} / \mathrm{mL}+ \\
15.62 \\
\mathrm{ng} / \mathrm{mL} \\
\end{array}$ & $\begin{array}{c}15.62 \\
\mathrm{ng} / \mathrm{mL}+ \\
15.62 \\
\mathrm{ng} / \mathrm{mL} \\
\end{array}$ & $\begin{array}{c}7.81 \\
\mathrm{ng} / \mathrm{mL}+ \\
15.62 \\
\mathrm{ng} / \mathrm{mL} \\
\end{array}$ & $\begin{array}{c}3.90 \\
\mathrm{ng} / \mathrm{mL}+ \\
15.62 \\
\mathrm{ng} / \mathrm{mL} \\
\end{array}$ & $\begin{array}{c}1.95 \\
\mathrm{ng} / \mathrm{mL}+ \\
15.62 \\
\mathrm{ng} / \mathrm{mL}\end{array}$ \\
\hline
\end{tabular}

\section{Multi caspase assay}

ApoTarget caspase colorimetric protease assay sample kit (KHZ1001, Invitrogen Corp., Camarillo, CA, USA) was used to determine the activity of caspase-2, 3, 6, 8 and 9. 
Treated and untreated cells $\left(3 \times 10^{6}\right.$ cells/well in 6-well plates) were collected and transferred into sterile test tubes and lysed using the cell lysis buffer supplied. Bradford Protein Assay Kit (Sigma Cat No: B6916) was used for determining the amount of protein in the derived supernatants. Samples $(50 \mu \mathrm{L})$ of the lysate were aliquoted into wells of a standard black 96-well microplate, to which $50 \mu \mathrm{L}$ of reaction buffer containing $10 \mathrm{mM}$ dithiothreitol were then added to the sample wells. The selective substrates used; VDVAD-pNA, DEVD-pNA, VEID-pNA, IETD-pNA and LEHD-pNA substrates for caspase-2, caspase-3, caspase-6, caspase- 8 and caspase- 9 , respectively were added to the appropriate wells $(5 \mu \mathrm{L}$ of $4 \mathrm{mM}$; final concentration $200 \mu \mathrm{M}$ ) and the plate was then incubated at $37^{\circ} \mathrm{C}$ for $4 \mathrm{~h}$. The absorbance at $405 \mathrm{~nm}$ was measured in a microplate reader (Thermo Labsystem Multiscan Spectrum, Thermolabsystem, Chantilly, VA, USA). To determine the change in caspase activity, the absorbance of treated samples compared with untreated control group.

\section{Assay for TNF-a}

The concentration of TNF- $\alpha$ in the supernatants of the cells was determined by enzyme linked immunosorbent assay (ELISA) as described by the manufacturer (KHC3011, Invitrogen Corp., Camarillo, CA, USA). Human TNF- $\alpha$ was used as standard, and serial dilutions (1000-15.6 pg/mL) were used to establish the standard curve. Average results from four independent experiments were compared to untreated and treated cells by measuring the optical density at $450 \mathrm{~nm}$.

\section{Western blot analysis}

Cell homogenates were studied by Standard Western blot techniques. Bradford Protein Assay Kit (Sigma Cat No: B6916) was used for determining the amount of protein in the derived supernatants. Briefly, $25 \mu \mathrm{g}$ of homogenate was separated on a $10 \%$ acrylamide gel by sodium dodecyl sulfate-polyacrylamide gel electrophoresis and transferred to polyvinylidene difluoride membranes (Hybond-P, Amersham Pharmacia Biotech, Piscataway, NJ) with a semidry transfer apparatus. The membranes were blocked with Tris Buffered Saline-5\% milk and then probed with a 1:2000, 1:100, 1:200 dilution of mouse monoclonal antibody for TRAIL (sc-65340), caspase-3 (sc-7272) and TNF- $\alpha$ (sc73343); respectively (Santa Cruz Biotechnology, Santa Cruz, CA, USA). The primary antibody was detected with a 1:10000 dilution of an anti-mouse peroxidase-conjugated secondary antibody (sc-2005; Santa Cruz Biotechnology, Inc., Santa Cruz, CA, USA). The membranes were washed, and blots were developed using an enhanced chemiluminescence Western blotting detection kit (ECL Plus kit, Amersham Biosciences RPN2132, USA) and exposed to X-ray film (Sigma C4729-1EA, Sigma Z363006-50) for 2-30 s. Molecular weight standards (Setalalaye Blue ${ }^{\circledR}$ Plus2, LC 5925, Life Technologies, USA) were used to determine molecular weights of the visualized bands.

\section{Statistical analysis}

All values are expressed as the mean \pm SEM. Analysis was performed using a professional statistics software program (Graph Pad InStat., San Diego, CA, USA). ANOVA 
with Dunnett's Multiple Comparison post-test and t-tests were used for intergroup comparisons. The graphs were drawn using Sigma Plot version 10.0 (SPSS Inc., Chicago, IL, USA) and CorelDRAW version X4 (Corel, Co., MN, USA) softwares. P < 0.05 was considered to be statistically significant.

\section{RESULTS}

\section{Cytotoxic effects of vinorelbine and endostatin}

At the end of $24 \mathrm{~h}$, vinorelbine did not show any cytotoxic effect on the $293 \mathrm{~T}$ cell line at any of the doses applied within $3.92 \mathrm{ng} / \mathrm{mL}-1 \mu \mathrm{g} / \mathrm{mL}$. However, at the end of 48 and $72 \mathrm{~h}$, all doses tested were observed to reduce the viability of $293 \mathrm{~T}$ cells significantly $(\mathrm{P}<0.001$; Figure 1A). At the end of the $24 \mathrm{~h}, 1 \mu \mathrm{g} / \mathrm{mL}(\mathrm{P}<0.01) ; 48 \mathrm{~h}, 250 \mathrm{ng} / \mathrm{mL}(\mathrm{P}<0.05), 500 \mathrm{ng} / \mathrm{mL}(\mathrm{P}<$ $0.01)$ and $1 \mu \mathrm{g} / \mathrm{mL}(\mathrm{P}<0.01) ; 72 \mathrm{~h}$, all tested doses $(\mathrm{P}<0.05$ and $\mathrm{P}<0.01)$ of vinorelbine were found to reduce the viability of MDAMB 231 cells (Figure1B).

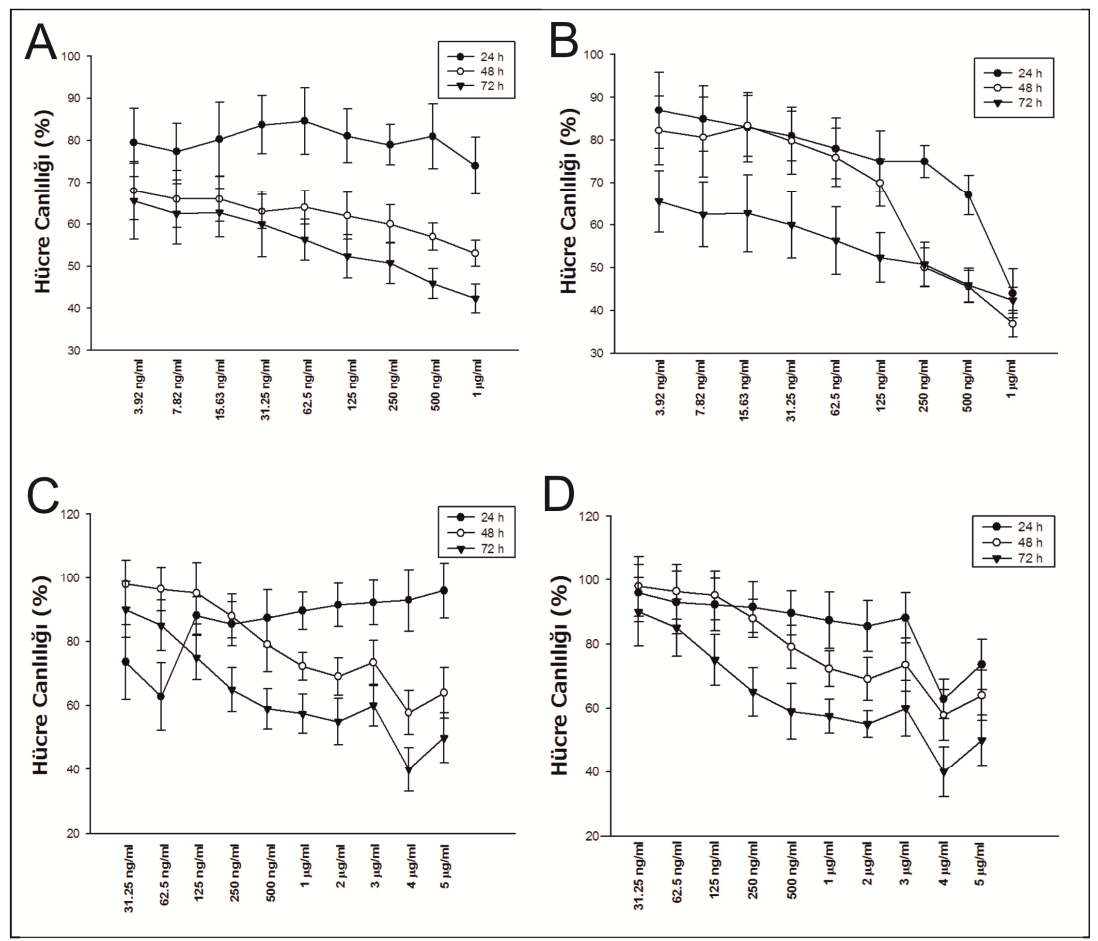

Figure 1. Percent cell viability treated with vinorelbine (VL) at doses within the $0.039 \mu \mathrm{g} / \mathrm{ml}-1 \mu \mathrm{g} / \mathrm{ml}$ range in 293T (A) and MDAMB 231(B) cells. Percent cell viability treated with endostatin (ES) at doses within the 0.039 $\mu \mathrm{g} / \mathrm{ml}-1 \mu \mathrm{g} / \mathrm{ml}$ range in 293T (C) and MDAMB 231(D) cells.

Endostatin did not exert any cytotoxic effects on $293 \mathrm{~T}$ cells at any of the tested doses, ranging from $31.25 \mathrm{ng} / \mathrm{mL}-5 \mu \mathrm{g} / \mathrm{mL}$ (Figure 1C). After $72 \mathrm{~h}$ incubation, $4 \mu \mathrm{g} / \mathrm{mL}$ endostatin was found to be the most effective dose ( $<<0.0001)$ on MDAMB 231 cell viability (Figure 1D). Based on the cytotoxicity test results; a combination trial was designed using doses ranging 
between $31.25 \mathrm{ng} / \mathrm{mL}$ and $5 \mu \mathrm{g} / \mathrm{mL}$ of endostatin and $15.62 \mathrm{ng} / \mathrm{mL}-1 \mu \mathrm{g} / \mathrm{mL}$ of vinorelbine on MDAMB 231 and $293 \mathrm{~T}$ cell viability. Endostatin at $4 \mu \mathrm{g} / \mathrm{mL}$ and vinorelbine at $1 \mu \mathrm{g} / \mathrm{mL}$ created the most cytotoxic effect on the breast cancer cells; $4 \mu \mathrm{g} / \mathrm{mL}$ endostatin alone caused $43 \%$ and $1 \mu \mathrm{g} / \mathrm{mL}$ vinorelbine alone caused $38 \%$ cytotoxicity on MDAMB 231 cells whereas the combination caused $53 \%$ cytotoxicity on cell viability. Endostatin at $4 \mu \mathrm{g} / \mathrm{mL}$ caused $32 \%$ and 1 $\mu \mathrm{g} / \mathrm{mL}$ vinorelbine alone caused $34 \%$ cytotoxicity on $293 \mathrm{~T}$ cells whereas the combination caused $10 \%$ cytotoxicity on cell viability at the end of $72 \mathrm{~h}$.

\section{The effects of endostatin, vinorelbine and their combination on caspase-2, $-\mathbf{3}$, - 6, -8 and -9 enzymes in the cells}

Following dose screening and combination studies, caspase-2, -3, -6, -8 and -9 enzyme activities of endostatin $(4 \mu \mathrm{g} / \mathrm{mL})$, vinorelbine $(1 \mu \mathrm{g} / \mathrm{mL})$ and the combination on the $293 \mathrm{~T}$ cells were assayed. The obtained data at the end of $72 \mathrm{~h}$ incubation period was displayed in the Figure 2 separately for each caspase. Caspase-2 enzyme activity increased by 11.11 times in vinorelbine treated cells compared to the control. While caspase-2 enzyme activity increased 2.39 times in endostatin treated cells compared to that of control, the combination increased caspase- 2 enzyme activity 3.35 times $(\mathrm{P}<0.01)$. Caspase-3 enzyme activity increased 13.45 and 4.18 times in vinorelbine and endostatin treated cells, respectively whereas the combination increased the enzyme activity 1.88 times compared to the relative control $(\mathrm{P}<0.01)$. Caspase- 6 enzyme activity increased 4.44 times in vinorelbine and 1.59 times in endostatin and vinorelbine combination treatment respectively although endostatin alone suppressed 1.14 times of caspase6 enzyme activity $(P<0.01)$. Since vinorelbine_and endostatin alone caused 19.37 and 1.45 times induction in caspase- 8 activity, the combination increased caspase- 8 enzyme activity 3.90 times compared to the relative control $(\mathrm{P}<0.01)$. Lastly, Caspase- 9 enzyme activity increased 21.80 and 2.85 times in vinorelbine and endostatin treated cells respectively but the combination caused 7.65 induction in the enzyme activity $(\mathrm{P}<0.01)$ (Figure 2$)$.
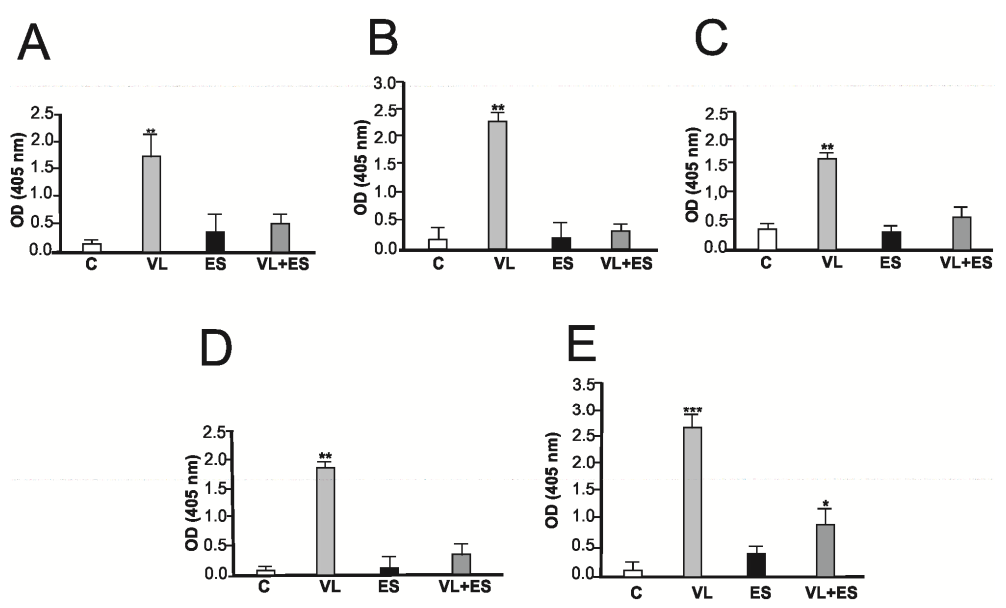

Figure 2. ApoTarget caspase colorimetric protease assay sample kit was used to determine the differences in the activity of caspase 2 (A), 3 (B), 6 (C), 8 (D) and 9 (E) in the $293 \mathrm{~T}$ cells $72 \mathrm{~h}$ after treatment with vinorelbine (VL), endostatin (ES) and their combination. Bradford Protein Assay Kit was used to determine the amount of total protein in the derived supernatants. Lysates containing $4 \mu \mathrm{g} / \mu \mathrm{L}$ total protein were assayed for determining the changes in caspase activities, $* * \mathrm{P}<0.001$ and $* \mathrm{P}<0.01$, significantly different compared to the control group; Student's T-test. 
Caspase-2, $-3,-6,-8$ and -9 enzyme activities of endostatin $(4 \mu \mathrm{g} / \mathrm{mL})$, vinorelbine (1 $\mu \mathrm{g} / \mathrm{mL})$ and the combination of both endostatin and vinorelbine doses $(4 \mu \mathrm{g} / \mathrm{mL}+1 \mu \mathrm{g} / \mathrm{mL})$ on the MDAMB 231 cell line were evaluated. Caspase-2 enzyme activity increased 5.85 and 1.15 times in vinorelbine and endostatin treated cells respectively while the combination caused 1.38 times induction compared to that of control $(\mathrm{P}<0.001)$. Vinorelbine and endostatin caused 4.16 $(\mathrm{P}<0.05)$ and $1.61(\mathrm{P}<0.01)$ times induction in caspase-3 enzyme activity respectively while the combination succeeded to increase the enzyme activity 1.01 times. Vinorelbine alone caused 2.87 times induction in caspase-6 enzyme activity whereas endostatin alone and endostatin combined with vinorelbine suppressed caspase- 6 enzyme activity 0.17 times and 8.80 times, respectively $(\mathrm{P}<0.01)$. Caspase- 8 enzyme activity increased 2.61 and 6.86 times increased in vinorelbine $(\mathrm{P}<0.05)$ and endostatin $(\mathrm{P}<0.01)$ treated cells since the combination suppressed caspase- 8 activity 4.48 times when compared to control cells. Finally, vinorelbine $(\mathrm{P}<0.01)$ and endostatin $(\mathrm{P}<0.01)$ alone caused 15.22 and 14.62 times induction in caspase- 9 enzyme activity respectively, while the combination caused 9 times induction of $(P<0.05)$ the enzyme activity compared to the relative control (Figure 3).
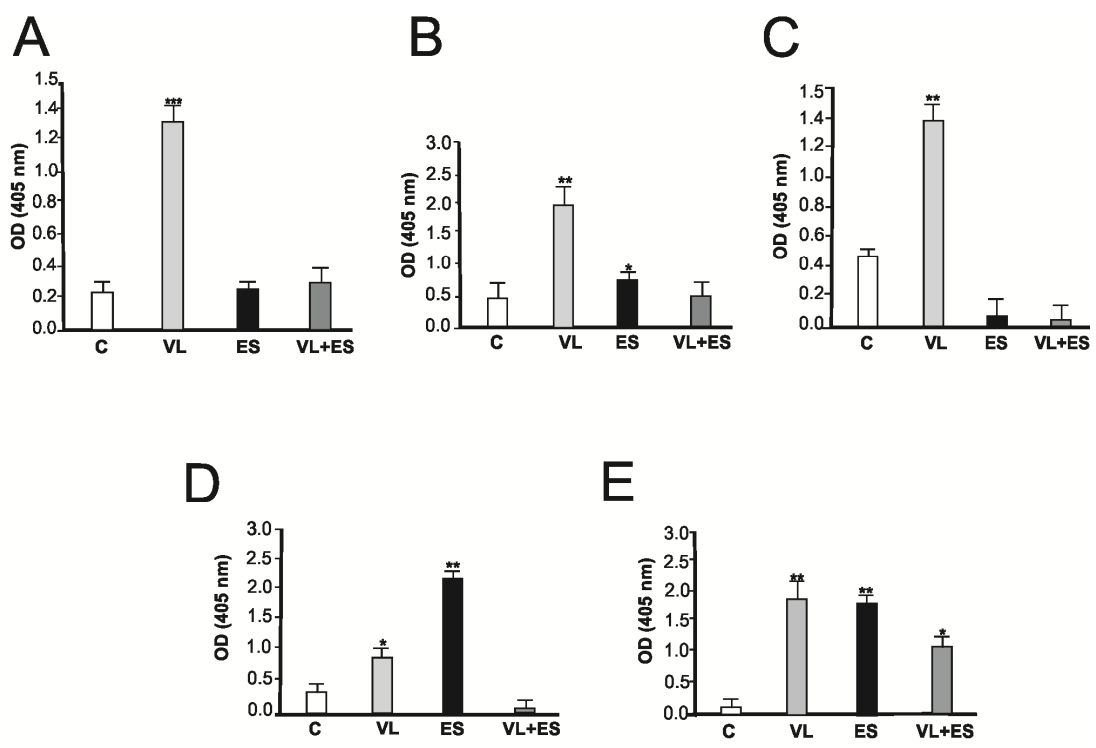

Figure 3. ApoTarget caspase colorimetric protease assay sample kit was used to determine the differences in the activity of caspase 2 (A), 3 (B), 6 (C), 8 (D) and 9 (E) in the MDAMB 231 cells $72 \mathrm{~h}$ after treatment with vinorelbine (VL), endostatin (ES) and their combination. Bradford Protein Assay Kit was used to determine the amount of total protein in the derived supernatants. Lysates containing $4 \mu \mathrm{g} / \mu \mathrm{L}$ total protein were assayed for determining the changes in caspase activities, $* * \mathrm{P}<0.001$ and $* \mathrm{P}<0.01$, significantly different as compared to the control group; Student's T-test.

\section{The effect of endostatin, vinorelbine and their combination on TNF- $\alpha$ concentration in the cells}

The effectiveness of endostatin, vinorelbine and the combination on TNF- $\alpha$ secretion in both $293 \mathrm{~T}$ and MDAMB 231 cells were evaluated. The amount of TNF- $\alpha$ increased 5.32 and 4.87 times in vinorelbine and endostatin treated $293 \mathrm{~T}$ cells, respectively since the combination increased the amount of TNF- $\alpha 1.27$ times compared to relative control (Figure 4A). On the other hand, the amount of TNF- $\alpha$ increased by 2.21 and 12.45 times with vinorelbine $(\mathrm{P}<0.05)$ 
and endostatin $(\mathrm{P}<0.01)$ treated MDAMB 231 cells respectively, whereas the combination increased the amount of TNF- $\alpha 8$ times $(\mathrm{P}<0.05)$ compared to the control (Figure 4B).
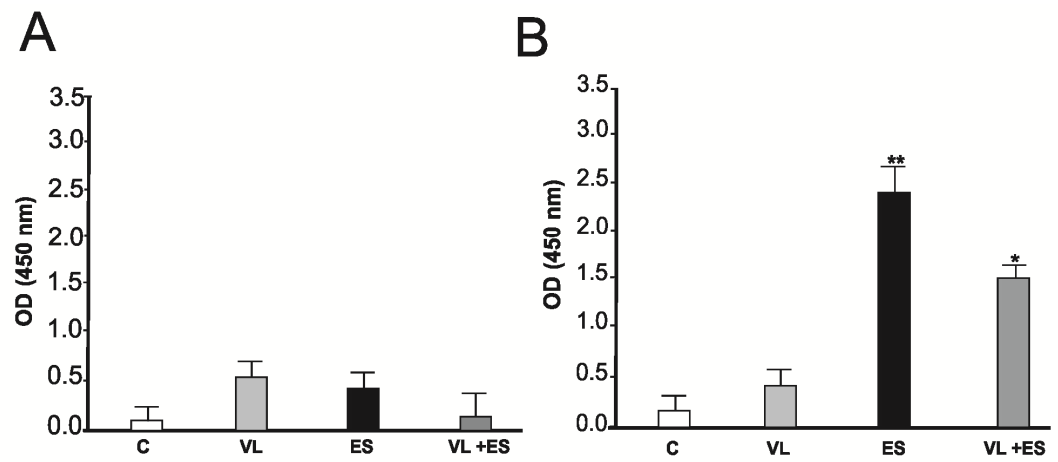

Figure 4. The expression of TNF- $\alpha$ in $293 \mathrm{~T}$ (A) and MDAMB 231 (B) cells following treatment for $72 \mathrm{~h}$ with vinorelbine (VL), endostatin (ES) and the combination was determined by ELISA. Each data value indicates the mean \pm SEM of four independent experiments. $* * \mathrm{P}<0.01$ and $* * * \mathrm{P}<0.001$, significantly different as compared to the control group; Student's T-test.

\section{Western-blot results of endostatin, vinorelbine and their combinations}

It was observed that in the MDAMB 231 cells, while the amount of TRAIL increased only with endostatin, the amount of TNF- $\alpha$ increased with both endostatin, vinorelbine and the combination treatment. The amount of caspase- 3 protein mostly increased in vinorelbine treated cells while a considerable increase was observed both with endostatin and the combination treated cells. GAPDH protein was used as an internal control for all groups tested (Figure 5).

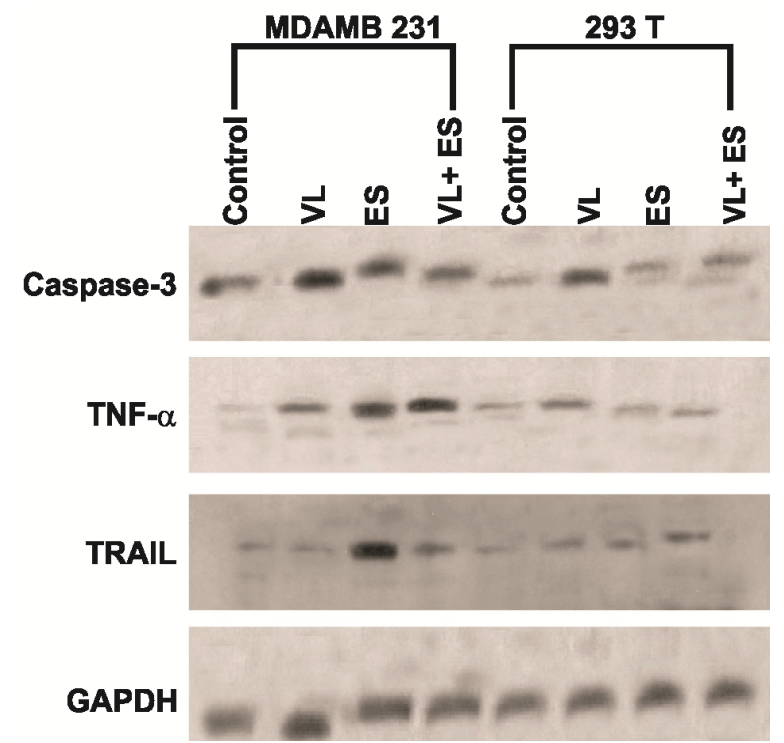

Figure 5. Lysates from $293 \mathrm{~T}$ and MDAMB 231 cells incubated with vinorelbine (VL), endostatin (ES) and the combination were analyzed by Western blotting for caspase-3, TNF- $\alpha$ and TRAIL protein expression levels. GAPDH was used as an internal control. 


\section{DISCUSSION}

Vinorelbine, which is a semi-synthetic vinca alkaloid used particularly in the treatment of lung and breast cancer, stops the cell cycle at G2/M phase by inhibiting tubulin polymerization. In this way, it causes the death of cells in the interphase stage (Aaproa and Finek, 2011). Vinorelbine has been among the most widely used chemotherapeutic agents in recent years because of its successful anticancer effects and less toxic side effects in breast cancer, when used alone (Zeybek et al., 2011). However as can be clearly seen from our results vinorelbine found to exert statistically significant cytotoxic effects on $293 \mathrm{~T}$ cells; especially at the end of 48 and $72 \mathrm{~h}$ incubation. Considering the cytotoxicity results, it can be clearly indicated that vinorelbine exhibits significant cytotoxic effects on normal cells and that is why it should be better to use vinorelbine in combination with other treatments to reduce toxic side effects (Johnson et al., 1996). According to our cytotoxicity test results, it is clear that the combination of endostatin with vinorelbine significantly suppressed the cytotoxicity of vinorelbine for normal cells.

Endostatin, which is an internal fragment of collagen XVIII of the basal membrane, has been considered as a potential angiogenic agent in recent years. Although many studies have been carried out since it was discovered in 1971, the mechanism of action of endostatin has not been fully elucidated yet. Although the anti-tumor effect of endostatin was demonstrated in vivo with many studies, that it does not create cytotoxic effect on tumor cells under the in vitro conditions is considered as generally accepted theory and supported by many scientists. Because endostatin is an anti-angiogenic peptide, its direct target is the endothelium, which enables the formation of new blood vessels, not the tumor cells (Shichiri et al., 2011). It has not been able to elucidated yet why endostatin is specific to endothelial cells, in other words, why it does not create a cytotoxic response to the cancer cells. In most studies, the in vitro and in vivo activities of endostatin are indicated to follow a biphasic dose response curve (Celik et al., 2005, Sjin et al., 2006). The anti-tumor effect of endostatin occurs at low doses and in long-term applications. The peptide that inhibitions tumor cells at a certain dose range does not create any effect over the threshold value. In the light of this information, potential effects of endostatin on $293 \mathrm{~T}$ and MDAMB 231 cells were evaluated primarily at low doses and within the longest incubation period available. Endostatin was used both alone and in combination with vinorelbine at a $0.039 \mu \mathrm{g} / \mathrm{mL}-1$ $\mu \mathrm{g} / \mathrm{mL}$ dose range in all cells. Endostatin did not exhibit any cytotoxic effects that can be considered statistically significant in $293 \mathrm{~T}$ cells within any of the incubation periods. The cell viability for the cells in which $1 \mu \mathrm{g} / \mathrm{mL}$ endostatin was applied, was calculated as $89.8 \%$ at the end of a $24 \mathrm{~h}$ incubation period. At the end of 48 and $72 \mathrm{~h}$ incubation periods, the calculated viability rate in the $293 \mathrm{~T}$ cells was found to be 92.6 and $94.7 \%$, respectively. Similarly, endostatin did not cause any cytotoxic effects in the MDAMB 231 cells at any doses up to $1 \mu \mathrm{g} / \mathrm{mL}$ within the tested incubation periods. The results obtained in both cell lines suggest that endostatin causes the formation of a biphasic dose-response curve in these cells as well. As stated above, the effect of endostatin depends on the dose and time. Although it is preferred to use endostatin at as possible as low concentrations, the findings suggest that it is necessary to change the concentration of endostatin. Therefore, the effect of endostatin at doses within $31.25 \mathrm{ng} / \mathrm{mL}$ and $5 \mu \mathrm{g} / \mathrm{mL}$ range was reinvestigated. It was found that the tested doses of endostatin within $31.25 \mathrm{ng} / \mathrm{mL}$ and $5 \mu \mathrm{g} / \mathrm{mL}$ range did not show any cytotoxic effect on $293 \mathrm{~T}$ cells compared to control group at the end of 24, 48 and 
$72 \mathrm{~h}$ incubation periods. However, it was observed that endostatin at higher doses than $1 \mu \mathrm{g} / \mathrm{mL}$ significantly reduced the cell viability of the MDAMB 231 cell line at the end of 24, 48 and $72 \mathrm{~h}$ incubation periods. At the end of $72 \mathrm{~h}, 4 \mu \mathrm{g} / \mathrm{mL}$ endostatin alone shows the most significant in vitro cytotoxic effect on MDAMB 231 cells. In many studies it has been stated that endostatin does not exert any cytotoxic effects on in vitro proliferation of tumor cells. Indraccolo et al. (2008) preincubated HUVEC cells with different amounts of DMEM, conditioned medium from MCF7 and MDA-MB435 cells transduced with the endostatin for $30 \mathrm{~min}$. They found that endostatin did not create a significant effect on in vitro proliferation of MCF-7 and MDAMB 435 human breast cancer cell lines. Though several studies indicate endostatin was no cytotoxic effects on tumor cells, there are also a few studies about cytotoxic effects of endostatin on tumor cells. Hajitou et al. (2002) demonstrated that endostatin suppressed VEGF expression in EF43.fgf-4 mouse breast cancer cells in vitro. Moreover Aydemir et al.(2011) also indicated that endostatin had cytotoxic effects on 4T1 and 4THMpc mouse breast cancer cell lines at appropriate dose and time periods. These results clearly indicate that endostatin can affect not only endothelial cells but also cancer cells directly in a dose and time dependent manner.

Paclitaxel (Bouillet et al., 2004), doksataksel (Mayerdowa et al., 2004), doxorubicin (Hochster et al., 2001), epirubicin (Frontni et al., 2005), mitoxantrone (Onyenadum et al., 2007), mitomycin (Bourgeois et al., 2007), gemcitabine (Gennetase et al., 2005), 5fluorouracil (Zambetti et al., 2000), cisplatin (Chehal et al., 2004), ifosfamide (Campisi et al., 1999) and capecitabine (Welt et al., 2005) are among some chemotherapeutic drugs giving positive results with vinorelbine when applied in combination. Vinorelbine has been used in combination with many chemotherapeutic agents; however, no study pointing its combination with an antiangiogenic agent was done so far. The possible synergistic effects of endostatin and vinorelbine in MDAMB 231 cells were evaluated in our study. Success of any combination therapy depends on the application of two different treatments at the appropriate doses. According to test results evaluated, the drugs showed synergistic cytotoxic effect at the end of $72 \mathrm{~h}$ incubation period by using $4 \mu \mathrm{g} / \mathrm{mL}$ endostatin and 1 $\mu \mathrm{g} / \mathrm{mL}$ vinorelbine together. It can be clearly indicated that, endostatin used in combination with vinorelbine in vitro potentiates the cytotoxic effect of endostatin on breast cancer cells. In contrast to what was found by many researchers, our findings clearly reveal that endostatin creates significant cytotoxic effect on the MDAMB 231 cell line when used at optimum doses and treatment period. A point to emphasized among the findings of our study is as follows: While endostatin and vinorelbine created cytotoxic effects in MDAMB 231 cells when used in combination, they did not create synergistic cytotoxic effects in 293 $\mathrm{T}$ cells. That means while vinorelbine induces cytotoxicity of endostatin in tumor cells, endostatin inhibits the cytotoxic effects of vinorelbine in normal cells. This means that this binary combination shows selective toxicity.

Endostatin triggers apoptosis in endothelial cells by changing intracellular $\mathrm{Ca}^{+2}$ and $\mathrm{Mg}^{+2}$ levels, affecting the activity of genes such as p53 or Bcl-2 (Quesada et al., 2006). Herein, we investigated whether the cytotoxic effect of endostatin in breast cancer cells is created via apoptosis. Induction of apoptosis was demonstrated by colorimetrically determining the change in the activities of caspase-2, $-3,-6,-8$ and -9 enzymes. Caspases are activated by the internal and external signals received from the cells. However, caspase3 is the one which finally initiates the death and therefore the increased expression of caspase-3 absolutely causes apoptosis in the cell (Hemst et al., 2007). In the study 
conducted by Dhanabal et al. (1999), endostatin showed no cytotoxic effect in NIH3T3 fibroblasts, A10 smooth muscle, H9c2 (2-1) myoblast cells. Renal carcinoma cells (786-0), fibroblasts (NIH3T3), lung fibroblasts (IMR-90), smooth muscle cells (A10) and myoblasts (H9c2 (2-1)) were treated with $10 \mu \mathrm{g} / \mathrm{mL}$ endostatin and no apoptotic change was recorded. No changes in caspase- 3 activity was detected in the aforementioned cells at the end of 2, 4, 8 and $14 \mathrm{~h}$ incubations but at the end of $24 \mathrm{~h}$ incubation period, while no difference in the caspase-3 activation in all non-endothelial cells was detected, caspase-3 activity has significantly changed only in NIH3T3 fibroblasts (Dhanabal et al., 1999) indicates that endostatin can cause an increase in the caspase enzyme activity in non-endothelial cells as well. The most important difference between our study and the study of Dhanabal et al. (1999), is the concentration of endostatin. In contrast to most agents, endostatin creates cytotoxic effects depending mainly on dose and incubation period. In our study, after 4 $\mu \mathrm{g} / \mathrm{mL}$ dose had been determined as the effective dose, cytotoxic effects of endostatin at higher doses $(5,7.5,10 \mu \mathrm{g} / \mathrm{mL})$ were re-investigated assuming that dose-response curve of endostatin was biphasic. Similar to the results of Dhanabal et al. (1999), endostatin did not exhibit cytotoxic effects at any dose on the increasing dose scale up to $10 \mu \mathrm{g} / \mathrm{mL}$.

Since vinorelbine is a cytotoxic drug, it caused more significant increase in all tested caspase activities of both $293 \mathrm{~T}$ and MDA MB 231 cells when compared with endostatin as an antiangiogenic drug. Vinorelbine enhanced the cytotoxic effect of endostatin on MDA MB 231 cells and that can clearly be seen from the fold increase in caspase activities. Since it is an anti-angiogenic agent, increasing the cytotoxicity of endostatin on MDAMB 231 cells is an important outcome of this study. While endostatin was administered alone, all tested caspase activities were lower than that of the combination with vinorelbine. On the other hand, endostatin significantly decreased the cytotoxic effects of vinorelbine in $293 \mathrm{~T}$ cells. We speculate that, when vinorelbine is used with endostatin, the non-desired toxic side effects will probably be decreased. So; both to increase the cytotoxic effects of endostatin in MDA MB 231 cells and minimize the cytotoxic effects of vinorelbine in normal epithelial cells, endostatin and vinorelbine can be successfully used together in combination.

Following dose screening studies, the effects of endostatin $(4 \mu \mathrm{g} / \mathrm{mL})$, vinorelbine $(1 \mu \mathrm{g} / \mathrm{mL})$ and their combination $(4 \mu \mathrm{g} / \mathrm{mL}+1 \mu \mathrm{g} / \mathrm{mL})$ on the amount of TNF- $\alpha$ protein in the $239 \mathrm{~T}$ cell line were investigated. While the amount of TNF- $\alpha$ increased 2.45 times when vinorelbine was used alone at $1 \mu \mathrm{g} / \mathrm{mL}$ dose compared to the control, the amount of TNF- $\alpha$ increased 0.346 times when endostatin was used alone at the $4 \mu \mathrm{g} / \mathrm{mL}$ dose. The combination $(4 \mu \mathrm{g} / \mathrm{mL}+1 \mu \mathrm{g} / \mathrm{mL})$ increased the amount of TNF- $\alpha 1.04$ times in these cells. It was found that at the end of $72 \mathrm{~h}$, the amount of TNF- $\alpha$ increased 4.99 times when vinorelbine was used alone at $1 \mu \mathrm{g} / \mathrm{mL}$ dose, 25.55 times when endostatin was used alone at $4 \mu \mathrm{g} / \mathrm{mL}$ dose and 17.5 times after the application of the combination on the MDAMB 231 cell line. Our results clearly indicated that endostatin potentiates secretion of TNF- $\alpha$ from vinorelbine treated MDA MB 231 cells.

It has been shown that endostatin performs its anti-angiogenic effect not by effecting directly tumor cells but creating apoptotic effect on the proliferation and invasion of endothelium coming together to create new blood vessels around the tumor. However, it was shown that endostatin directly creates cytotoxic effect over MDAMB 231 breast cancer cells as a result of the experiments carried out strictly in our study. The results of ELISA both detected the activation of caspases and the increase in the amount of TNF- $\alpha$ were 
supported with western-blot assays. The amount of TRAIL protein was only shown with western-blot technique. It was observed that the amount of TRAIL increases only in the MDAMB 231 cells to which endostatin was applied. Endostatin increases the amount of TNF- $\alpha$ and TRAIL and caspase 8 activity, showing that this antiangiogenic agent activates the extrinsic pathway of apoptosis rather than caspase-dependent intrinsic pathway.

In our study, it was revealed that endostatin exerts cytotoxic effects on MDAMB 231 breast cancer cells through caspase- 8 activation and TNF- $\alpha$ and TRAIL stimulation. It was also found out that endostatin, as an anti-angiogenic agent ameliorates the cytotoxic effects of vinorelbine in normal cells. However, vinorelbine enhances the cytotoxic activity of endostatin in breast cancer cells.

\section{ACKNOWLEDGMENTS}

This work was supported by The Scientific Research Projects Coordination Unit of Akdeniz University and by The Scientific and Technological Research Council of Turkey (TUBITAK) with 2010.02.0121.032 grant numbers and with 111T613.

\section{CONFLICTS OF INTEREST}

The authors declare no conflict of interest.

\section{REFERENCES}

Aaproa M and Finek J (2011). Oral vinorelbine in metastatic breast cancer: A review of current clinical trial results.. Cancer Treat. Rev. 38: 120-126.

Ai J, Li J, Ga L, Yun G, et al. (2016). Multifunctional near-infrared fluorescent nanoclusters for simultaneous targeted cancer imaging and photodynamic therapy. Sens. Actuator B-Chem. 222: 918-922.

Amarante-Mendes GP and Griffith TS (2015). Therapeutic applications of TRAIL receptor agonists in cancer and beyond. Pharmacol. Therapeut. 155: 117-131.

Amirzada MI, Ma X, Gong X, Chen Y, et al. (2014). Recombinant human interleukin 24 reverses Adriamycin resistance in a human breast cancer cell line. Pharmacol. Rep. 66: 915-919.

Aydemir EA, Oz ES, Göktürk RS, Ozkan G, et al. (2011). Glycyrrhiza flavescens subsp. antalyensis exerts antiproliferative effects on melanoma cells via altering TNF- $\alpha$ and IFN- $\alpha$ levels. Food Chem. Toxicol. 49: 820-828.

Bouillet T, Saintigny P, Levy E, Spano JP, et al. (2004). Weekly paclitaxel (P) combined with biweekly vinorelbine (V) in metastatic breast cancer (MBC): Final results of a clinical phase II study. J. Clin. Oncol. 22: 783.

Bourgeois H, Turpin F, Bouchada M, Volters A, et al. (1998). Mitomycin-vinorelbine as second line chemotherapy in metastatic breast cancer. Bull Cancer. 85: 794.

Campisi C, Fabi A, Papaldo P, Tomao S, et al. (1999). Ifosfamide given by continuous-intravenous infusion in association with vinorelbine in patients with anthracycline-resistant metastatic breast cancer: a phase I-II clinical trial. Cancer Chemoth. Pharm. 44: 1-4.

Celik I, Sürücü O, Dietz C, Heymach JV, et al. (2005). Therapeutic Efficacy of Endostatin Exhibits a Biphasic DoseResponse Curve. Cancer Res. 65: 11044-11050.

Chehal A, Taher A, Khalil M and Shamseddine A (2004). Cisplatin plus vinorelbine (PVn) as a salvage regimen for refractory breast cancer. Breast. 13: 421-4.

Connolly EM, Harmey JH, O'grdy T, Foley D, et al. (2002). Cyclo-oxygenase inhibition reduces tumour growth and metastasis in an orthotopic model of breast cancer. Br. J. Cancer. 87: 231-7.

Dhanabal M, Volk R, Ramchandran R, Simons M, et al. (1999). Cloning, expression, and in vitro activity of human endostatin. Biochem. Biophys. Res. Commun. 258: 345-52.

Frontini L, Ardizzoia A, Giordano M, Fagnani D, et al. (2005). Epirubicine-vinorelbine (EV) intravenous combination followed by oral vinorelbine (VNR) as first-line treatment in advanced breast cancer (ABC) patients:A POLONORD group study. J. Clin. Oncol. 23: 770.

Gennatas C, Michalaki V, Mouratidou D, Andreadis C, et al. (2006). Gemcitabine in combination with vinorelbine for heavily pretreated advanced breast cancer. Anticancer Res. 26: 549-552. 
Ghavami S, Hashemi M and Ande SR (2009). Apoptosis and cancer: mutations within caspase genes. J. Med. Genet. 46: 497-510.

Hajitou A, Grignet C, Devy L, Berndt S, et al. (2002). The antitumoral effect of endostatin and angiostatin is associated with a down-regulation of vascular endothelial growth factor expression in tumor cells. Faseb J. 16: 1802-1804.

Hayakawa A, Kawamoto Y, Nakajima H, Sakai J, et al. (2008). Bid truncation mediated by caspases-3 and -9 in vinorelbine-induced apoptosis. Apoptosis. 13: 523-530.

Heemst D, Reijer PM and Westendorp RGJ (2007). Ageing or cancer: A review on the role of caretakers and gatekeepers. Eur. J. Cancer. 43: 2144-2152.

Hochster HS, Vogel CL, Burman SL and White R (2001). Activity and safety of vinorelbine combined with doxorubicin or fluorouracil as first-line therapy in advanced breast cancer: a stratified phase II study. Oncologist. 6: 269-77.

Indraccolo S, Gola E, Rosato A, Minuzzo S, et al. (2002). Differential effects of angiostatin, endostatin and interferonalpha(1) gene transfer on in vivo growth of human breast cancer cells. Gene Ther. 9: 867-78.

Jemal A, Bray F, Center MM, Ferlay J, et al. (2011). Global cancer statistics. CA Cancer J. Clin. 61: 69-90.

Johnson SA, Harper P, Hortobagyi GN, and Pouillart P (1996). Vinorelbine: an overview. Cancer Treat. Rev. 22(2): $127-42$.

Kalluri R (2003). Basement membranes: Structure, assembly and role in tumor angiogenesis. Nat. Rev. Cancer. 3: 422433.

Kars MD, Iseri OD, Gunduz U and Molnar J (2008). Reversal of multidrug resistance by synthetic and natural compounds in drug-resistance MCF-7 cell lines. Chemotherapy. 54: 194-200.

Lin G, Zhu W, Yang L, Wu J, et al. (2014). Delivery of siRNA by MRI visible nanovehicles to overcome drug resistance in MCF 7/ADR human breast cancer cells. Biomaterials. 35: 9495-9507.

Mayordomo JI, Milla A, Morales S, Yubero A, et al. (2004).Biweekly docetaxel and vinorelbine as first-line chemotherapy in metastatic breast cancer. Clin. Breast Cancer. 5: 131-5.

O'Reilly MS, Boehm T, Shing Y, Fukai N, et al. (1997). Endostatin: An endogenous inhibitor of angiogenesis and tumor growth. Cell. 88: 277-85.

Onyenadum A, Gogas H, Markopoulos C, Bafaloukos D, et al. (2007). Mitoxantrone plus vinorelbine in pretreated patients with advanced breast cancer. J. Chemotherapy. 19(5): 582-9.

Ozben T (2007). Oxidative stress and apoptosis: impact on cancer therapy. J. Pharmacol. Sci. 96: 2181-96.

Qesada AR, Munoz-Chapuli R and Medina MA (2006). Anti-Angiogenic Drugs: from Bench to Clinical Trials. Med. Res.Rev. 26: 483-530.

Ravishankar D, Rajora AK, Greco F and Osborn HM (2013). Flavonoids as prospective compounds for anti-cancer therapy. Int. J. Biochem. Cell B. 45: 2821-2831.

Salvesen GS and Dixit VM (1997). Caspases: intracellular signaling by proteolysis. Cell. 91: 443-6.

Shichiri M and Hirata Y (2011). Antiangiogenesis signals by endostatin. Faseb. J. 15(6):1044-53.

Sjin RMTT, Naspinski J, Birsner AE, Li C, et al. (2006). Endostatin therapy reveals a U-shaped curve for antitumor activity. Cancer Gene Ther. 13: 619-627.

Welt A, Minckwitz G and Oberhoff C (2005). Phase I/II study of capecitabine and vinorelbine in pretreated patients with metastatic breast cancer. Ann. Oncol. 16: 64-9.

Wen W, Moses MA, Wiederschain D, Arbiser JL, et al. (1999). The generation of endostatin is mediated by elestase. Cancer Res. 59: 6051-6056.

Wiley SR, Schooley K, Smolak PJ, Din WS, et al. (1995). Identification and characterization of a new member of the TNF family that induces apoptosis. Immunity. 3: 673-682.

Zambetti M, Mariani G, Demicheli R, Verderio P, et al. (2000). Five-day infusion fluorouracil plus vinorelbine in women with breast cancer previously treated with anthracyclines and paclitaxel. Breast Cancer Res. Treat. 62: 1359.

Zeybek ND, Inan S, Ekerbicer N, Vatansever HS, et al. (2011). The effects of Gemcitabine and Vinorelbine on inducible nitric oxide synthase (iNOS) and endothelial nitric oxide synthase (eNOS) distribution of MCF-7 breast cancer cells. Acta Histochem. 113: 62-67.

Zu C, Zhang M, Xue H, Cai X, et al. (2015). Emodin induces apoptosis of human breast cancer cells by modulating the expression of apoptosis-related genes. Oncol. Lett. 10: 2919-2924. 